University of Nebraska - Lincoln

DigitalCommons@University of Nebraska - Lincoln

1988

\title{
Revision of the schausi Group of Anastrepha Schiner (Diptera: Tephritidae), with a Discussion of the Terminology of the Female Terminalia in the Tephritoidea
}

\author{
Allen L. Norrbom \\ Systematic Entomology Lab., AHS-USDA, BBII, \% National Museum of Natural History, NHB 168, \\ Washington, D.C. 20560 \\ Ke Chung Kim \\ The Frost Entomological Museum, The Pennsylvania State University, 106 Patterson Bldg., University Park, \\ PA 16802
}

Follow this and additional works at: https://digitalcommons.unl.edu/entomologyother

Part of the Entomology Commons

Norrbom, Allen L. and Kim, Ke Chung, "Revision of the schausi Group of Anastrepha Schiner (Diptera: Tephritidae), with a Discussion of the Terminology of the Female Terminalia in the Tephritoidea" (1988). Entomology Papers from Other Sources. 101.

https://digitalcommons.unl.edu/entomologyother/101

This Article is brought to you for free and open access by the Entomology Collections, Miscellaneous at DigitalCommons@University of Nebraska - Lincoln. It has been accepted for inclusion in Entomology Papers from Other Sources by an authorized administrator of DigitalCommons@University of Nebraska - Lincoln. 


\title{
Revision of the schausi Group of Anastrepha Schiner (Diptera: Tephritidae), with a Discussion of the Terminology of the Female Terminalia in the Tephritoidea
}

\author{
ALLEN L. NORRBOM' AND KE CHUNG KIM²
}

\begin{abstract}
Ann. Entomol. Soc. Am. 81(2): 164-173 (1988)
ABSTRACT Monophyly of a group of four species of Anastrepha is proposed based on characters of the head and the male terminalia. The group includes A. schausi Aldrich; A. fernandezi Caraballo; A. hermosa Norrbom, n. sp.; and A. bellicauda Norrbom, n. sp. Sexual dimorphism in these species is noted. A discussion of morphological terminology in the Tephritoidea, especially concerning female terminalia, is presented.
\end{abstract}

KEY WORDS Insecta, ovipositor, sexual dimorphism, fruit flies

\begin{abstract}
Anastrepha Schiner is the largest and the most economically important genus of true fruit flies (Tephritidae) in the American tropics and subtropics (Stone 1942). In this paper we recognize the monophyly of a group of four Anastrepha species, two of which are new to science, as part of a project to revise the genus and analyze the phylogenetic relationships among its species. We also discuss the homologies of the parts of the female terminalia in the Tephritoidea as well as the various terminologies that have been used for these parts. We hope our discussion will lead to the standardization of this terminology among tephritid workers.

Acronyms for the institutions that loaned specimens for this study are given in the acknowledgment section. The acronym USNM represents the National Museum of Natural History, Smithsonian Institution, Washington, D.C.
\end{abstract}

\section{Morphological Terminology}

Students of Diptera are fortunate to have a detailed, comprehensive reference on adult fly morphology, by McAlpine (1981). White (in press) has further explained and amply illustrated McAlpine's terminology as it applies to the Tephritidae. We follow the terms of those authors for the most part, but we believe it is important to thoroughly discuss the few areas where we disagree. These terms should be brought to the attention of other dipterists before they become dogma through general usage. This is especially important for the terminology of the female terminalia of the Tephritoidea, which was not treated in detail by McAlpine.

' Systematic Entomology Lab., ARS-USDA, BBII, $\%$ National Museum of Natural History, NHB 168, Washington, D.C. 20560.

2 The Frost Entomological Museum, The Pennsylvania State University, 106 Patterson Bldg., University Park, PA 16802.
We use the term "microtrichose" rather than "pruinose" or "tomentose" to refer to areas of the integument bearing microtrichia (Norrbom \& Kim in press), and we follow the terminology of Stone (1942) for the wing pattern of Anastrepha. McAlpine (1981) and White (in press) did not discuss the one to two pairs of setae near the anterior margin of the scutum that are differentiated in many tephritids (e.g., most Trypetinae). We continue to call these the "scapular setae" (Munro 1947, Foote 1980).

With regard to wing venation, we follow Steyskal (1984) in the terminology of the cubital veins. Steyskal asserts that what McAlpine (1981) calls the posterior cubitus (CuP) is merely a fold or spurious vein. Whether or not this is correct, it is unnecessary and cumbersome to add the suffix "A," for "Anterior," to what have traditionally been called " $\mathrm{Cu}_{1}$ " and " $\mathrm{Cu}_{2}$." The use of the abbreviations " $\mathrm{CuA}_{1}$ " and " $\mathrm{CuA}_{2}$ " is confusing because of the proximity of the anal veins, and especially because $\mathrm{Cu}_{2}$ fuses with $\mathrm{A}_{1}$ in the Muscomorpha and many other Brachycera. Even if the structure in question is the posterior cubitus, it is unnecessary to use McAlpine's terminology because this structure is of little taxonomic importance. McAlpine himself continued to call the posterior medial vein simply " $\mathrm{M}$ " because the anterior medial vein (MA) is very small, and he maintained the traditional terminology for the radial veins, although technically incorrect. We also follow Steyskal in using the abbreviation "bcu" for the basal cubital cell ("cup" of McAlpine [1981]; "anal cell" of many earlier workers [e.g., Steyskal 1977]), but we use the abbreviation " $\mathrm{m}$ " (White in press) for the cell apical to dm-cu and posterior to M ("am" of Steys$\mathrm{kal}$ [1984]), and " $\mathrm{cu}_{1}$ " for the cell posterior to $\mathrm{Cu}_{1}$ ("acu" of Steyskal [1984]).

In the male terminalia, we use the term "interparameral sclerite" (Griffiths 1972) rather than "sternite 10" for the bridgelike ventral sclerite that 
Table 1. Comparison of some terminologies used for the female terminalia in the Tephritoidea

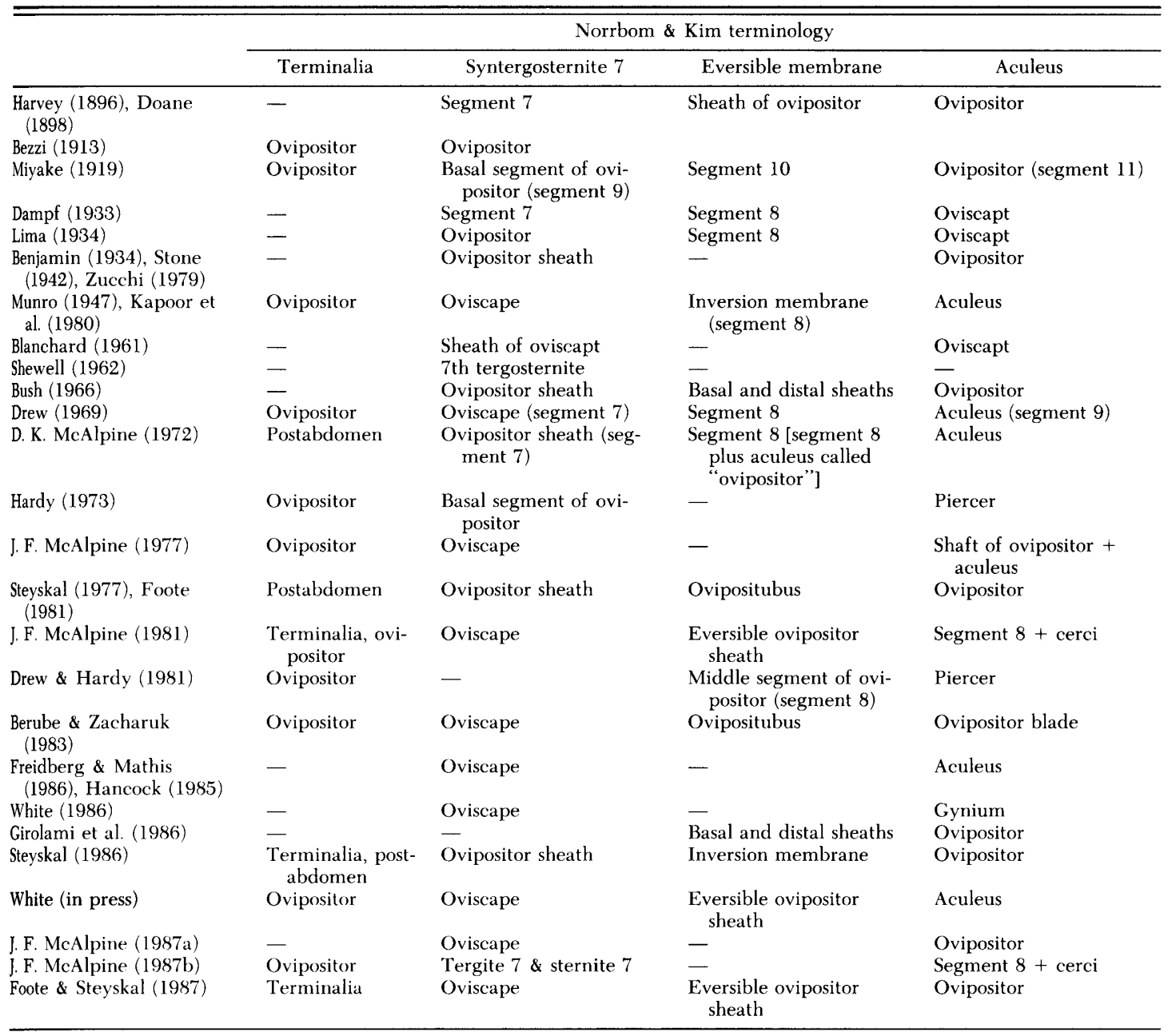

fuses with the inner surstyli in the Tephritidae. Griffiths (1981) reviewed evidence that this sclerite is derived from the 9 th rather than 10 th segment. We call the apical part of the aedeagus the "distiphallus" (White in press); the use of "glans" (McAlpine 1981) seems redundant.

A confounding variety of morphological terms (Table 1) has been used for the parts of the female terminalia in the Tephritoidea, resulting from confusion about homology as well as from semantics. We present a detailed discussion of this terminology because the special modifications of the terminalia in the Tephritoidea were treated only briefly by McAlpine (1981) and because his terminology for these parts has not been universally accepted (see Table 1). There are discrepancies in this terminology even among the chapters on the families of Tephritoidea in the Manual of Nearctic Diptera, Volume 2 (e.g., compare McAlpine [1987b] and Foote \& Steyskal [1987]).

The elongate, telescoping terminalia of the female Tephritoidea include the seventh and more apical segments of the abdomen. There are varying degrees of sclerotization and fusion occurring in the different families, but three or four main parts are usually present (Fig. 1): 1) tergite 7 and sternite 7 , which are fused to form a basal, conical or tubelike sclerite (here called "syntergosternite 7"), except in the Piophilidae and some taxa of Pallopteridae (e.g., Eurygnathomyia Czerny) whose classification is controversial (Griffiths 1972, McAlpine 1977); 2) an elongate membrane, here termed the "eversible membrane," that is normally inverted inside the basal sclerite(s); 3) an elongate segment 8 , the tergite and especially the sternite of which are usually split longitudinally; and 4) an apical part formed from the cerci and perhaps elements of segment 9. Except in the subfamily Epiplateinae of the Richardiidae (Steyskal 1987b), the cerci are at least partially fused. In most Tephritidae and in some taxa in other families, they are strongly sclerotized and fused to the tergite(s) of segment 8 , forming a structure which is here called the "aculeus" (Fig. 1). 


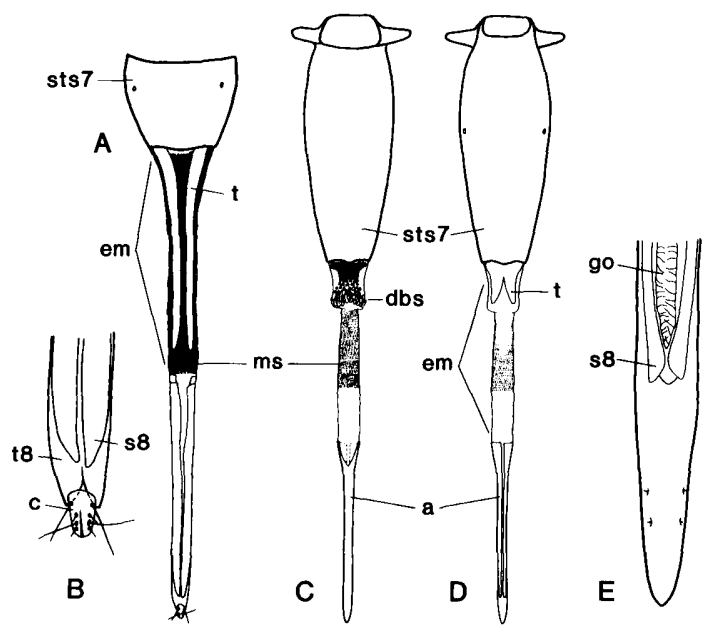

Fig. 1. Female terminalia: (A-B) Physiphora demandata (F.) (Otitidae); (C-E) Anastrepha nigrifascia Stone; A, C, ventral view; $B$, tip of segment 8 and cerci; $D$, dorsal view; E, tip of aculeus; a, aculeus; c, cerci; dbs, dorsobasal sclerotized scales; em, eversible membrane; go, genital opening; ms, sclerotized scales of eversible membrane; sts7, syntergosternite 7; s8, sternite 8; t, taen-

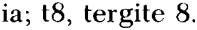

Much of the confusion in the terminology of the female tephritoid terminalia is the result of different uses of the term "ovipositor." This term has long been used in association with female Tephritoidea (e.g., Loew 1873), but early authors often applied it in a vague or dual sense; for example, Loew (1873) discussed the length of the "ovipositor," apparently referring only to the visible, basal part of the terminalia. Bezzi (1913) used "ovipositor" for the entire terminalia and for the basal part alone, and Miyake (1919) used "ovipositor" for the entire terminalia and for just the apical parts (i.e., the aculeus). As the terminalia were used taxonomically to a greater extent, the term "ovipositor" was used with greater precision. Most American workers (e.g., Benjamin 1934, Dean 1935, Stone 1942, Uhler 1951, Bush 1966, Zucchi 1979, Foote 1981, Steyskal 1977, 1984, Hernández-Ortiz 1985, Girolami et al. 1986, Foote \& Steyskal 1987, McAlpine 1987a), following Harvey (1896) and Doane (1898), have called only the apical part(s) of the terminalia (i.e., the aculeus) the ovipositor. Others (e.g., Hendel 1914, Hering 1941, Munro 1947, Aczél 1949a, McAlpine 1962, 1977, 1981, 1987b, Drew 1969, Hardy 1973, Stoltzfus 1977, Kapoor et al. 1980, Berube \& Zacharuk 1983) referred to the entire terminalia with the term. Adding to the confusion, Lima (1934) also used "ovipositor" only for the basal part of the terminalia, and D. K. McAlpine (1972) included what is here termed the eversible membrane plus the apical parts of the terminalia in what he called the "ovipositor."

We agree with White (in press) that “ovipositor" should be applied to the entire female terminalia in the Tephritoidea, although this usage is perhaps redundant. This usage is more consistent with that in other Muscomorpha (McAlpine 1981), although there is confusion in some families similar to that in the Tephritidae. For example, in the Agromyzidae, Hendel (1931) called the entire terminalia the ovipositor; Frick (1952) and Griffiths (1980) used "ovipositor" in a dual sense, for just the apical parts of the terminalia and for the entire terminalia (at least they refer to the fused tergite and sternite of segment 7 as the "basal segment of the ovipositor" [Frick 1952] or the "basal cone of ovipositor" [Griffiths 1980]); and Spencer \& Steyskal (1986) used "ovipositor" only for the apical parts.

It has been argued that the term "ovipositor" should not be used for Diptera at all, but reserved for the "true," appendicular type of ovipositor, as in the Orthoptera. Richards \& Davies (1977), for example, suggest that when the female Diptera abdomen is elongated and specially modified for egg-laying, it is more correctly called an "oviscapt." The independent origin of the egg-laying organ in female flies has long been recognized, however, and the same terms are often applied to analogous structures in unrelated organisms (Snodgrass 1935, 1963), for example, "wing" in birds, bats, and insects. In addition, oviscapt, derived from

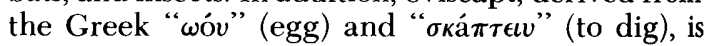
not functionally descriptive (Steyskal 1986); even in the Tephritidae, no fruit tissue is removed or dug out during oviposition, and the term is certainly not descriptive of the type of terminalia in most other Muscomorpha. "Oviscapt" has been used in the Tephritidae only for the two fused apical parts of the terminalia (i.e., the aculeus) (e.g., Dampf 1933, Lima 1934, Blanchard 1961), and its further usage would be inappropriate.

Probably a majority of recent workers on the Tephritoidea (e.g., Munro 1947, Hering 1953, Aczél 1958, Drew 1969, Griffiths 1972, McAlpine 1977, 1981, Stoltzfus 1977, Kapoor et al. 1980, Berube \& Zacharuk 1983, Hancock 1985, Freidberg \& Mathis 1986, White 1986) use the term "oviscape" (or "oviscap") for the basal sclerite of the terminalia. Derived from the Latin "ovum" (egg) and "scapus" (shaft, stalk, cylinder, or trunk), this term is also functionally inaccurate (Steyskal 1986), however; the sclerite obviously is not a shaft or any part of the egg, and a perhaps intended meaning such as "egg-cylinder" or "egg-tube" would apply to the entire terminalia. In addition to "oviscape," the basal part of the terminalia has also been called the following terms or their vernacular translations: "ovipositor" (Lima 1934), "basal segment (or part) of the ovipositor" (Hendel 1914, Miyake 1919, Hering 1941, Aczél 1949a, Hardy 1973); "sheath of oviscapt" (Blanchard 1961); and “ovipositor sheath" (Benjamin 1934, Stone 1942, Aczél 1955 [in descriptions], Bush 1966, Steyskal 1977, 1984, Zucchi 1979). We see no need for the use of vernacular names for this structure. Harvey (1896), Doane (1898), Dampf (1933), Dean (1935), and Uhler (1951) called it simply "segment 7," but the entire 
segment would also include the eversible membrane. We propose to call it "syntergosternite 7," which clearly indicates its homology with just the sclerites of segment 7. Shewell (1962) used the similar term "seventh tergosternite" for Senopterina (Platystomatidae). In taxa where tergite 7 and sternite 7 are separate (e.g., in Eurygnathomyia), a special term is unnecessary.

The homology of the eversible membrane of female Tephritoidea has not been fully resolved. It is clearly not segment 8 or segment 10 as it was termed by some authors (e.g., Miyake 1919, Dampf 1933, Lima 1934, Munro 1947, McAlpine 1962, Drew 1969, Kapoor et al. 1980, Drew \& Hardy 1981, Berube \& Zacharuk 1983); the genital opening, which occurs between segments 8 and 9 in female Diptera (McAlpine 1981), serves as a landmark to indicate the homology of the true segment 8. The membrane consists partly, or perhaps entirely (Steyskal 1986), of the elongated conjunctiva or intersegmental membrane of segment 7 , but in many families (e.g., the Tephritidae, Lonchaeidae, Pallopteridae, Otitidae, and Richardiidae) there are a dorsal and a ventral pair of longitudinal sclerotized strips, called "taeniae" by Steyskal (1984), that may be derived from the sclerites of segment 7 (Foote \& Steyskal 1987, Steyskal 1987b). The latter hypothesis is especially suggested by the terminalia of the Piophilidae, in which the apical parts of tergite 7 and sternite 7 are weak and taenia-like and partially invert (McAlpine 1987b). The taeniae vary considerably in size, however, sometimes extending almost the entire length of the membrane, and it does not seem possible to consistently recognize parts of the membrane as being derived from the conjunctiva or the sclerites. Steyskal (1986) also suggested that taeniae could be derived from the conjunctiva, at least in some families.

The eversible membrane could be termed the "conjunctiva of segment 7," but, as noted above, it may very likely be derived from more than just this structure. This terminology is also somewhat cumbersome. Other terms used for the membrane include: "inversion membrane" (Munro 1947, Kapoor et al. 1980), “ovipositubus" (Steyskal 1977, Foote 1981, Berube \& Zacharuk 1983), "eversible ovipositor sheath" (McAlpine 1981, White in press), or "basal and distal sheath," "sheath," or "sheath of ovipositor" (Harvey 1896, Doane 1898, Dean 1935, Uhler 1951, Bush 1966, Girolami et al. 1986). Certainly, "eversible ovipositor sheath" and "sheath of ovipositor" are inappropriate if the term "ovipositor" is applied to the entire terminalia rather than only to the parts apical to the membrane. If anything, the membrane would be a sheath for the aculeus. "Ovipositubus," which means literally "egg placing or laying tube," is applicable to the entire terminalia. There is little difference between "eversible membrane" and "inversion membrane," but we prefer the former because the membrane is normally inside the syntergosternite and it usually has to be everted rather than inverted.
The eversible membrane is almost entirely membranous in the Pyrgotidae (Steyskal 1987a), but in many tephritoid families, in addition to taeniae, it bears minute dorsal and ventral sclerotized scales, which are perhaps best developed in the Tephritidae. In many tephritids, such as Anastrepha and Rhagoletis Loew, the scales are absent from the apical part of the membrane, but it is not possible to consistently divide the membrane into basal and distal parts on this basis as Dean (1935) suggested for Rhagoletis. In other taxa, such as Blepharoneura Loew, the membrane has scales along its entire length. These scales were termed "rastral spicules" by Stoltzfus (1977), whereas Steyskal (1984, 1986) called them "rasper teeth," following Stone (1942), who actually applied the term "rasper" only to the group of large, toothlike scales found dorsally on the expanded basal part of the membrane in most Anastrepha. Stone (1942) and Steyskal (1984, 1986), perhaps following Dampf (1933), assumed that the scales are used to abrade the surface of plant tissue before oviposition; but, although a female tephritid does bend her terminalia forward under her thorax during oviposition, and either the dorsal or ventral surface of the membrane could be brought into contact with the plant tissue, no explicit observations of this use of the scales have ever been reported, and we doubt that this is their function. Drew \& Hardy (1981) suggested that the scales provide strength to the membrane, while still allowing it the flexibility to retract inside syntergosternite 7. The large scales found in Anastrepha, and also in Toxotrypana Gerstaecker, may hold the base of the aculeus in place during oviposition. If so, this may explain why the extreme base of the aculeus is usually abruptly expanded in these taxa.

The apical part of the terminalia is fused to tergite 8 in most Tephritidae and in a number of taxa in other tephritoid families (e.g., Dasiops Rondani in the Lonchaeidae, at least some Palloptera Fallén in the Pallopteridae, and some Chaetopsis Loew and Euxesta Loew in the Otitidae). When this occurs, a special term is needed for this composite sclerite. Besides "ovipositor" and "oviscapt" (see above), the terms "apical part of the ovipositor" (Aczél 1958), “piercer” (Hardy 1973), “ovipositor blade" (Berube \& Zacharuk 1983), “gynium" (White 1986), and "aculeus" (Munro 1947, Drew 1969, Stoltzfus 1977, Kapoor et al. 1980, Hancock 1985, Freidberg \& Mathis 1986, White in press) have also been used. We believe the Latin "aculeus," which means literally "little needle," is the most appropriate. "Piercer" is functionally accurate, but it and "ovipositor blade" and "apical part of ovipositor" are less desirable terms because they are vernacular. "Gynium" may refer only to segment 8. It should be noted that McAlpine (1977) called segment 8 the "shaft of the ovipositor" and applied "aculeus" only to the free, apical part of the terminalia in the Piophilidae. Where these two structures are not fused, it seems more reasonable to call them simply "segment 8 " and the "cerci" 
or the "fused cerci" (McAlpine 1981), and to use "aculeus" only to refer to them in combination. The so-called "egg guides" (Stoltzfus 1977), "valves" or "ventral sclerites" or "processes" (Dean 1935, Berube \& Zacharuk 1983, Girolami et al. 1986) of the aculeus are the sternites of segment 8 .

The length of the tip of the aculeus is an important species-level taxonomic character in $A n$ astrepha. Previous authors (e.g., Stone 1942, Steyskal 1977) defined this length as from the genital opening ("end of oviduct" of Steyskal [1977]) to the extreme tip of the aculeus, but they actually measured from the inner margin of the sclerotized area on the ventral side (Fig. $4 \mathrm{D}$, arrow) to the apex. The genital opening, which is surrounded by a fringe of fine, hairlike microtrichia, is slightly basal to this margin (Fig. 1E). Frequently it is difficult to see. In Tephritidae, the tip of the aculeus usually bears several large sensilla in a ventral or ventrolateral groove on each side, in addition to numerous smaller dorsal and ventral sensilla. In Anastrepha, the ventrolateral grooves are weak, but there are normally three ventrolateral sensilla, with the basal two usually larger than the apical one (Dampf 1933, Stone 1942, Baker et al. 1944). Girolami et al. (1986) have demonstrated chemosensory and mechanosensory functions for the ventrolateral sensilla in Rhagoletis pomonella (Walsh).

\section{The schausi Group}

The schausi group includes four species in which the facial carina ("clypeal ridge" of Stone [1942]) is weak, the surstylus is acute in posterior view, with the outer and usually inner margin concave (Fig. 4A), and the distiphallus bears numerous small spinelike structures (Fig. 4B). The males also have the face or facial ridge marked with black or pale white or the abdomen distinctly bicolored, or both. The included species can be further characterized as follows: katepisternal seta moderately to well developed; c- and s-bands, if present, well separated; vein $R_{2+3}$ without strong bends; vein $M$ weakly curved apically; terminalia moderately long, syntergosternite 7 of female at least $3.50 \mathrm{~mm}$ long, aedeagus $4.90-6.10 \mathrm{~mm}$ long; male proctiger uncreased, with sclerotized area undivided; endophallic sclerite (Fig. 4B) expanded apically and involuted.

The weak facial carina, the shape of the surstylus, and the spinose distiphallus are all derived character states and strongly indicate the monophyly of these four species, but their relationships to other species of Anastrepha remain poorly understood. They might be related to the punctata group (Steyskal 1977), in which the katepisternal seta is similarly well developed, the medial vein is weakly curved apically, and the wing pattern is similar, with the c- and s-bands separated. This hypothesis is not well supported, however; the first two characters are plesiomorphic, and all three are variable in at least one other species group of $A n$ - astrepha. The host plants and immature stages of the schausi group are unknown, as are the females of three of the four species. The white spots on the head and the abdominal coloration of the male of A. fernandezi Caraballo are absent in the female, and these characters are probably sexually dimorphic in the other species. The face is expanded and the carina is weak in both sexes of A. fernandezi, however.

Within the group, A. bellicauda Norrbom, n. sp. is probably the sister taxon of the other three species, which have the face short, the facial ridge expanded and bicolored, and the scutum and abdominal tergites with similar microtrichial patterns, all of which appear to be derived character states. The bicolored abdomen is probably convergent in $A$. bellicauda, because the pattern differs from that in A. fernandezi and A. hermosa Norrbom, n. sp. This character suggests the monophyly of the latter two species, which also have only white markings on the facial ridge.

Anastrepha bellicauda Norrbom, n. sp. (Fig. 2A and 3)

Diagnosis. A. bellicauda differs from all other Anastrepha in its wing pattern. In Steyskal (1977), it might be keyed to $A$. doryphoros Stone, but $A$. doryphoros has $\mathrm{M}$ strongly curved apically and the scutum with nonmicrotrichose stripes. A. doryphoros also has much longer female terminalia (syntergosternite $7 \mathrm{ca} .9 .0 \mathrm{~mm}$ long in the holotype) than would be expected in A. bellicauda; estimating from the length of the aedeagus, syntergosternite 7 in A. bellicauda is probably ca. $3.5 \mathrm{~mm}$ long. The color pattern and stout setae of the abdomen of the male of A. bellicauda are also distinctive.

Description. Male. Mostly bright yellow; setae blackish; setulae yellow. Head. Entirely yellow except ocellar tubercle; face microtrichose, carina weak; gena narrow, height $<0.10$ longest diameter of eye; posterior orbital seta well developed; ocellar seta weak; first flagellomere moderately long, length 0.67 height of face. Thorax. Mesonotum $3.50 \mathrm{~mm}$ long; scutum and scutellum entirely microtrichose; scutal color pattern weak, with faint postsutural lateral vitae; katepisternal setae missing in type, but large alveolus present; subscutellum and mediotergite entirely yellow; pleural color pattern indistinct. Wing (Fig. 2A). Length $7.52 \mathrm{~mm}$; diffusely yellow, without distinct pattern; $M$ very weakly curved apically, meeting costa at slight angle. Male abdomen (Fig. 3A). Syntergite $1+2$ yellow, entirely microtrichose; tergites 3 and 4 with apical half dark brown and lateral margin with row of 7-9 stout, blackish setae, entirely microtrichose; tergite 5 dark brown except medial 1/4, dark areas each with 9-10 stout, blackish setae, dark areas without microtrichia; surstylus (Fig. 3B) moderately long, flat, acute, with inner and outer margins slightly concave; aedeagus $4.95 \mathrm{~mm}$ long, 1.41 times as long as mesonotum; distiphallus (Fig. 


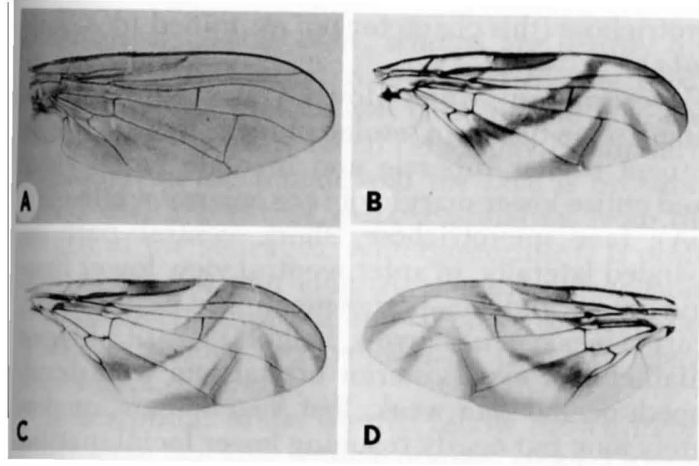

Fig. 2. Wings: A, A. bellicauda; B, A. fernandezi C, A. hermosa; D, A. schausi.

3C) $0.59 \mathrm{~mm}$ long, with numerous minute apical spines, endophallic sclerite expanded and involuted apically; proctiger uncreased laterally, weakly sclerotized. Female. Unknown.

Etymology. The name of this species is derived from the Latin "bellus" (beautiful) and "cauda" (tail), in reference to the striking abdomen.

Type Material. Holotype $\delta$, PANAMA: El Cermeño, "Fruit fly trap," "4621," XII-1939-I-1940 (J. Zetek) (USNM).

\section{Anastrepha fernandezi Caraballo}

(Fig. 2B and 4)

Anastrepha fernandezi Caraballo, 1985: 26. Holotype 9 , VENEZUELA: Aragua, Rancho Grande, 1,100 m, 4-VI-1958 (F. Fernández-Yépez) (Universidad Central de Venezuela, Maracay) (not examined).

Diagnosis. A. fernandezi differs from all $A n$ astrepha except $A$. hermosa Norrbom and $A$. schausi Aldrich by the shape of the face, particularly the angulate lower margin. It differs from these two species in wing pattern. Males of $A$. fernandezi are readily recognized by the white spot on the facial ridge. The scutal and abdominal microtrichia patterns, the weak facial carina, and the male abdominal color pattern are also useful diagnostic characters. Females would probably key to A. aphelocentema Stone, A. nunezae Steyskal, or A. greenei Lima in Steyskal (1977); these species have normally shaped faces with strong carinae, and at least A. aphelocentema and A. nunezae lack the median stripe of microtrichia on the scutum in A. fernandezi.

Description. Mostly yellow brown to orange; setae blackish; setulae orange. Head. Orange except ocellar tubercle and in male creamy white oval spot on facial ridge; face microtrichose, short, ventral part expanded laterally, in anteroventral view lower margin of face and facial ridge meeting at ca. $90^{\circ}$ angle, carina weak; gena narrow, height 0.11-0.13 longest diameter of eye; posterior orbital seta well developed; ocellar seta weak; first flagellomere moderately long but nearly reaching
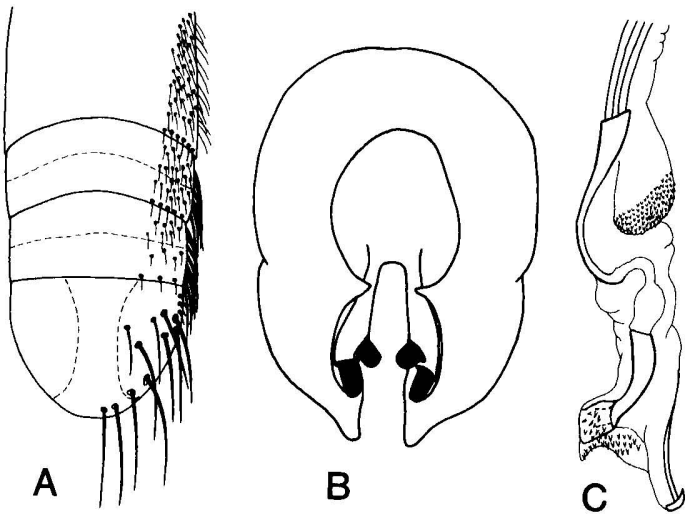

Fig. 3. A bellicauda: A, male abdominal tergites (setae shown only along right margin; area posterior to dotted line on tergites 3 and 4 , and lateral to dotted lines on tergite 5 are dark brown); B, male terminalia, posterior view (proctiger and aedeagus omitted); C, distiphallus.

lower facial margin, length $0.84-0.85$ height of face. Thorax. Mesonotum 2.96-3.78 mm long; scutum without microtrichia except narrow medial stripe, slightly expanding posteriorly, and lateral to supra-alar seta; scutum mostly orange, with narrow pale medial stripe and white postsutural lateral vittae; scutellum microtrichose; katepisternal setae strong, about as long as outer vertical seta; subscutellum and mediotergite entirely orange; pleural color pattern indistinct. Wing (Fig. 2B). Length 7.88-9.96 mm; with typical Anastrepha pattern, bands light to moderate brown, very narrow, not connected; v-band interrupted at apex; $M$ weakly curved apically, well separated from apex of s-band. Male abdomen. Syntergite $1+2$ orange; tergites 3-5 with broad lateral dark brown stripes, meeting at posterior margin of tergite 5 ; tergites with median stripe of dense microtrichia, nearly
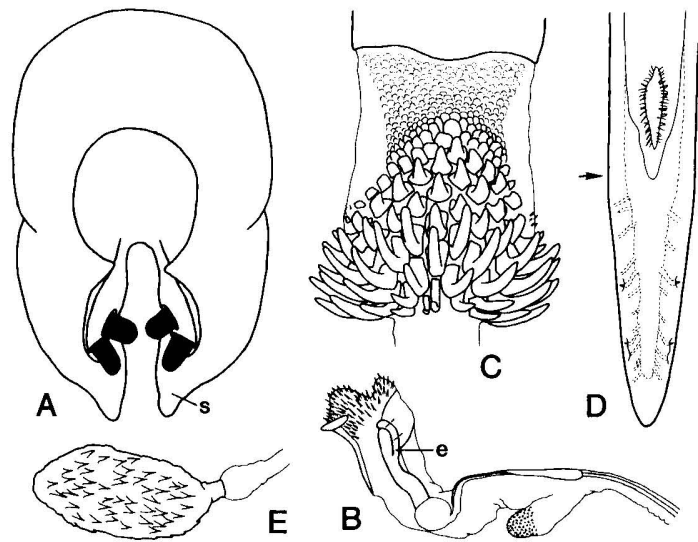

Fig. 4. A. fernandezi: A, male terminalia, posterior view (proctiger and aedeagus omitted); $\mathrm{B}$, distiphallus; $\mathrm{C}$, base of female conjunctiva 7 , dorsal view; $D$, apex of aculeus, ventral view; E, spermatheca; e, endophallic sclerite; s, surstylus. 


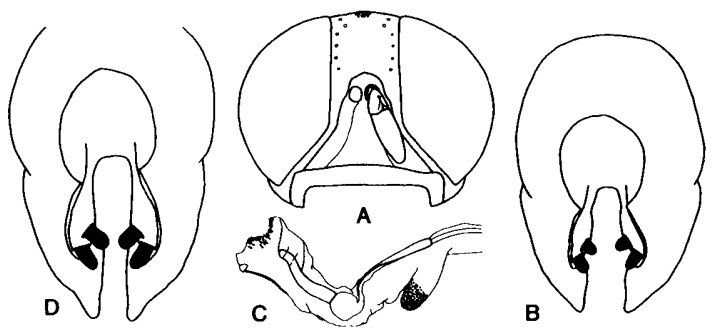

Fig. 5. (A-C) A. hermosa; (D) A. schausi; A, head, anterior view; $\mathrm{B}, \mathrm{D}$, male terminalia, posterior view (proctiger and aedeagus omitted); $\mathrm{C}$, distiphallus.

corresponding with light-colored area, producing silvery appearance at certain angles; surstylus (Fig. 4A) moderately long, flat, acute, with outer margin slightly concave, inner margin straight to slightly concave; aedeagus $5.87 \mathrm{~mm}$ long, 1.85 times as long as mesonotum; distiphallus (Fig. 4B) $0.55 \mathrm{~mm}$ long, with numerous minute apical spines, endophallic sclerite expanded and involuted apically; proctiger uncreased laterally, weakly sclerotized. Female $a b$ domen. Tergites mostly light brown; with median microtrichose stripe, narrow on tergite 4 , expanding on tergites 5 and 6 ; syntergosternite 74.30 $5.06 \mathrm{~mm}$ long; eversible membrane (Fig. 4C) with ca. 40 hooklike dorsobasal scales in 5-6 rows, gradually increasing in length apically; aculeus 4.00$4.36 \mathrm{~mm}$ long, base gradually but distinctly expanded, tip (Fig. 4D) 0.30-0.32 mm long, ca. 0.11 $\mathrm{mm}$ wide at base, nonserrate, in paratype examined, basal peglike ventrolateral sensilla well separated; spermathecae (Fig. 4E) elongate ovoid.

Remarks. Most of the quantitative characters in this description were taken from Caraballo (1985).

Distribution. Known only from the state of Aragua, Venezuela.

Material Examined. VENEZUELA: Aragua, Rancho Grande, 1,100 m, 28-V-1953 (C. J. Rosales), 1 ô (UCD); same locality, 5-VI-1958 (C. J. Rosales), 1 \& paratype (USNM); same locality, 5-VI-1958 (F. Fernández-Yépez), 1 ơ paratype (USNM).

Anastrepha hermosa Norrbom, n. sp. (Fig. 2C and $5 \mathrm{~A}-\mathrm{C}$ )

Diagnosis. Males of A. hermosa are readily distinguished from other Anastrepha by the expanded face with the lower margin white, and by the abdominal color and microtrichia patterns. Females probably have the face similarly shaped, or at least with the carina weak. Estimating from the length of the aedeagus, the female syntergosternite 7 is probably ca. $4.5 \mathrm{~mm}$ long. A. scobinae Stone, A. hastata Stone, and A. tubifera (Walker), which are known only from females, have wing patterns similar to that of $A$. hermosa and terminalia of corresponding length, but they all have well-developed facial carinae and are doubtfully conspecific. A. tubifera also has $\mathrm{M}$ much more strongly curved apically, and it also has the scutum entirely mi- crotrichose (this character not examined in A. hastata).

Description. Male. Mostly yellow brown to orange; setae blackish; setulae orange. Head. Orange except ocellar tubercle and in male facial ridge and entire lower margin of face creamy white (Fig. 5A); face microtrichose, short, ventral part expanded laterally, in anteroventral view lower margin of face and facial ridge meeting at ca. $90^{\circ}$ angle, carina weak; gena narrow, height 0.13-0.15 longest diameter of eye; posterior orbital seta well developed; ocellar seta weak; first flagellomere moderately long but nearly reaching lower facial margin, length ca. $0.78-0.80$ height of face. Thorax. Mesonotum 3.14-3.62 mm long; scutum microtrichose except broad stripes lateral to acrostichal setae and mesal to dorsocentral setae, from anterior to posterior margin; scutum mostly orange, with narrow pale medial stripe and white postsutural lateral vittae; scutellum microtrichose; katepisternal setae strong, about as long as outer vertical seta; subscutellum and mediotergite entirely orange; pleural color pattern indistinct. Wing (Fig. 2C). Length 8.14-8.72 mm; with typical Anastrepha pattern, bands light to moderate brown, not connected; v-band complete; $M$ weakly curved apically, well separated from apex of s-band. Male abdomen. Syntergite $1+2$ mostly orange, with lateral dark brown stripes on apical half; tergites 3 and 4 with broad lateral dark brown stripes; tergite 5 entirely dark brown; syntergite $1+2$ and tergites 3 and 4 with median stripe of dense microtrichia, nearly corresponding with light-colored area, producing silvery appearance at certain angles; surstylus (Fig. 5B) moderately long, flat, acute, with outer margin nearly straight, inner margin slightly concave; aedeagus $6.28 \mathrm{~mm}$ long, 2.00 times as long as mesonotum; distiphallus (Fig. 5C) $0.60 \mathrm{~mm}$ long, with numerous minute apical spines, endophallic sclerite expanded and involuted apically; proctiger uncreased laterally, weakly sclerotized. Female. Unknown.

Remarks. The type locality is probably on the Río Pinchis in eastern Departamento Pasco in central Peru.

Etymology. The name of this species is the Spanish word for handsome or beautiful.

Type Material. Holotype $\delta$, PERU: Pichis, Pto. Yessup, XII-1903 (SMTD). Paratype ô, BOLIVIA: S. Antonio, "Anastrepha obliqua Macq. det. Kertesz” (TMB).

\section{Anastrepha schausi Aldrich} (Fig. 2D and 5D)

Anastrepha schausi Aldrich, 1925: 3; Greene, 1934: 168; Lima, 1934: 514; Stone, 1942: 37; Aczél, 1949b: 226; Foote, 1967: 15; Steyskal, 1977: 10. Holotype o, COSTA RICA: Juan Viñas, 11.i (W. Schaus and J. T. Barnes) (USNM, no. 26837) (examined). 
Diagnosis. Males of A. schausi are readily distinguished from other Anastrepha by the broad facial ridge and the brown band on the face and the facial ridge. The facial ridge may be similarly expanded in the female and the face is probably short, with the carina weak. Estimating from the length of the aedeagus, syntergosternite 7 is probably about $4.2 \mathrm{~mm}$ long. A. schausi differs from the Anastrepha species known only from females (discussed under $A$. hermosa) by the same characters as A. hermosa.

Description. Male. Mostly yellow brown to orange; setae blackish; setulae orange. Head. Orange except ocellar tubercle and in male facial ridge and lower margin of face with narrow dark brown band; male facial ridge also with white above brown band; face microtrichose, short, but not expanded laterally, carina weak; facial ridge extremely broad, almost reaching lateral margin of head; gena narrow, height 0.14 longest diameter of eye; posterior orbital seta well developed; ocellar seta weak; first flagellomere dark brown apically, moderately long but nearly reaching lower facial margin, length 0.86 height of face. Thorax. Mesonotum $3.71 \mathrm{~mm}$ long; scutum without microtrichia except along transverse suture, narrow medial stripe, expanding just anterior to dorsocentral seta to cover posterior margin, and lateral to supra-alar seta; scutum mostly orange, with pale white postsutural lateral vittae; scutellum microtrichose; katepisternal setae strong, almost as long as outer vertical seta; subscutellum and mediotergite entirely orange; pleural color pattern indistinct. Wing (Fig. 2D). Length $8.96 \mathrm{~mm}$; with typical Anastrepha pattern, bands moderate brown, not connected; v-band complete; $M$ weakly curved apically, well separated from apex of s-band. Male abdomen. Tergites concolorous light brown, with median stripe of dense microtrichia, producing silvery appearance at certain angles; surstylus (Fig. 5D) moderately long, flat, acute, with outer and inner margins slightly concave; aedeagus 5.92 $\mathrm{mm}$ long, 1.59 times as long as mesonotum; distiphallus $0.60 \mathrm{~mm}$ long, with numerous minute apical spines, endophallic sclerite expanded and involuted apically; proctiger uncreased laterally, weakly sclerotized. Female. Unknown.

Distribution. Known only from the type locality in Costa Rica.

\section{Acknowledgment}

The following institutions and individuals kindly loaned the specimens examined in this study: British Museum (Natural History) (BMNH), B. R. Pitkin and I. M. White; Természettudományi Múzeum, Budapest (TMB), L. Papp; Staatliches Museum für Tierkunde, Dresden (SMTD); and University of California, Davis (UCD), R. 0 . Schuster. We acknowledge the late Francisco Fernández Yépez, Instituto de Zoología Agrícola, Universidad Central de Venezuela, Maracay, for the kind gift of two paratypes of A. fernandezi to the USNM collection. I. M. White (C. A. B. International Institute of Entomology), A. Freidberg (Tel Aviv University), and the other participants in the tephritid workshop at the First International Congress of Dipterology (Budapest, August 1986) provided useful comments on the terminology of the female terminalia. We also thank G. C. Steyskal and R. H. Foote (Systematic Entomology Laboratory, retired) for helpful discussions about terminology. M. E. Schauff, R. V. Peterson (Systematic Entomology Laboratory), L. F. Jiron (Universidad de Costa Rica), and I. M. White reviewed early drafts of the manuscript, for which we are grateful. This paper was authorized for publication as Paper No. 7581 in the Journal Series of the Pennsylvania Agricultural Experiment Station as a contribution from the Frost Entomological Museum (AES Project No. 2594).

\section{References Cited}

Aczél, M. L. 1949a. A revision of the genus "Xanthaciura" Hendel (Trypetidae. Dipt.) based on Argentine species. Acta Zool. Lilloana 8: 111-146.

1949b. Catalogo de la familia "Trypetidae" (Dipt. Acalypt.) de la Región Neotropical. Acta Zool. Lilloana $7: 177-328$.

1955. Fruit flies of the genus Tomoplagia Coquillett (Diptera, Tephritidae). Proc. U.S. Natl. Mus. 104: 321-411.

1958. Revision of the American species of the genus Acinia Robineau-Desvoidy (Diptera, Trypetidae). Rev. Bras. Entomol. 8: 75-106.

Aldrich, J. M. 1925. New Diptera or two winged flies in the United States National Museum. Proc. U.S. Natl. Mus. 66: 1-36.

Baker, A. C., W. E. Stone, C. C. Plummer \& M. MePhail. 1944. A review of studies on the Mexican fruitfly and other related Mexican species. U.S. Dep. Agric. Misc. Publ. 531.

Benjamin, F. H. 1934. Descriptions of some native trypetid flies with notes on their habits. U.S. Dep. Agric. Tech. Bull. 401

Berube, D. E. \& R. Y. Zacharuk. 1983. The abdominal musculature associated with oviposition in two gall-forming tephritid fruit flies in the genus Urophora. Can. J. Zool. 61: 1805-1814.

Bezzi, M. 1913. Indian Trypaneids (fruit-flies) in the collection of the Indian Museum. Mem. Indian Mus. 3: 54-175.

Blanchard, E. E. 1961. Especies argentinas del género Anastrepha Schiner (sens. lat.) (Diptera, Trypetidae). Rev. Investig. Agric. (Buenos Aires) 15: 281-342.

Bush, G. L. 1966. The taxonomy, cytology, and evolution of the genus Rhagoletis in North America (Diptera, Tephritidae). Bull. Mus. Comp. Zool. 134: 431562

Caraballo, J. 1985. Nuevas especies del género Anastrepha Schiner, 1868 (Diptera: Tephritidae) de Venezuela. Bol. Entomol. Venez. 4: 25-32.

Dampf, A. 1933. Estudio sobre el oviscapto de las moscas de la fruta (Anastrepha spp.) de México. Irrigacion en México 6: 253-265.

Dean, R. W. 1935. Anatomy and postpupal development of the female reproductive system in the apple maggot fly, Rhagoletis pomonella Walsh. N.Y. State Agric. Exp. Stn., Geneva, Tech. Bull. 229.

Doane, R. W. 1898. A new trypetid of economic importance. Entomol. News 9: 69-72.

Drew, R. A. I. 1969. Morphology of the reproductive system of Strumeta tryoni (Froggatt) (Diptera: Trypetidae) with a method of distinguishing sexually mature adult males. J. Aust. Entomol. Soc. 8: 21-32. 
Drew, R. A. I. \& D. E. Hardy. 1981. Dacus (Bactrocera) opiliae, a new sibling species of the dorsalis complex of fruit flies from northern Australia (Diptera: Tephritidae). J. Aust. Entomol. Soc. 20: 131137.

Foote, R. H. 1967. Family Tephritidae. In P. E. Vanzolini \& N. Papavero [eds.], A catalogue of the Diptera of the Americas south of the United States. Fasc. 57.

1980. Fruit fly genera south of the United States (Diptera: Tephritidae). U.S. Dep. Agric. Tech. Bull. 1600.

1981. The genus Rhagoletis Loew south of the United States (Diptera: Tephritidae). U.S. Dep. Agric. Tech. Bull. 1607 .

Foote, R. H. \& G. C. Steyskal. 1987. Tephritidae, pp. 817-831. In J. F. McAlpine [ed.], Manual of Nearctic Diptera, vol. 2. Agriculture Canada, Monograph No. 28. Ottawa.

Freidberg, A. \& W. N. Mathis. 1986. Studies of Terelliinae (Diptera: Tephritidae): a revision of the genus Neaspilota Osten Sacken. Smithson. Contrib. Zool. 439.

Frick, K. E. 1952. A generic revision of the family Agromyzidae (Diptera) with a catalogue of New World species. Univ. Calif., Berkeley, Publ. Entomol. 8: 339-452.

Girolami, V., A. Strapazzon, P. Pietra, R. Crnjar, A. M. Angioy, J. G. Stoffolano, Jr., \& R. J. Prokopy. 1986. Behavior and sensory physiology of Rhagoletis pomonella in relation to oviposition stimulants and deterrents in fruit, pp. 183-190. In R. Cavalloro [ed.], Fruit flies of economic importance 84 . Balkema, Rotterdam.

Greene, C. T. 1934. A revision of the genus Anastrepha based on a study of the wings and on the length of the ovipositor sheath (Diptera: Trypetidae). Proc. Entomol. Soc. Wash. 36: 127-179.

Griffiths, G. C. D. 1972. The phylogenetic classification of Diptera Cyclorrhapha with special reference to the structure of the male postabdomen. Junk, The Hague.

1980. Studies on boreal Agromyzidae (Diptera) XIV. Chromatomyia miners on Monocotyledones. Entomol. Scand., Suppl. 13: 1-61.

1981. Book review of "Manual of Nearctic Diptera," vol. 1. Bull. Entomol. Soc. Can. 13: 49-55.

Hancock, D. L. 1985. Trypetinae (Diptera: Tephritidae) from Madagascar. J. Entomol. Soc. South. Afr. 48: 283-301.

Hardy, D. E. 1973. The fruit flies (Tephritidae-Diptera) of Thailand and bordering countries. Pacif. Ins. Monogr. 31

Harvey, F. L. 1896. The currant fly. Epochra canadensis Loew. Maine State College Experiment Station, Augusta, Maine.

Hendel, F. 1914. Die Bohrfliegen Südamericas. Abh. Ber. Königl. Zool. Anthrop. Ethnograph. Mus. Dresden (1912) 14: 1-84.

1931. Agromyzidae. In E. Lindner [ed.], Die Fliegen der Palaearktischen Region Bd. VI, No. 59: 1-64

Hering, E. M. 1941. Trypetidae (Dipt.), pp. 121-176. In Beiträge zur Fauna Perus, Bd. 1.

1953. Neue Fruchtfliegen von China, Vorderasien, Brasilien und Guatemala. Siruna Seva 8: 1-16.

Hernández-Ortiz, V. 1985. Descripcion de una nueva especie méxicana del género Rhagoletis Loew (Diptera: Tephritidae). Fol. Entomol. Mex. 64: 73-79.

Kapoor, V. C., D. E. Hardy, M. L. Agarwal \& J. S. Grewal. 1980. Fruit fly (Diptera: Tephritidae) systematics of the Indian Subcontinent. Export India Publications, Jullundur.
Lima, A. da Costa. 1934. Moscas de frutas do genero Anastrepha Schiner, 1868 (Diptera: Trypetidae). Mem. Inst. Oswaldo Cruz 28: 487-575.

Loew, H. 1873. Monographs of the Diptera of North America. Part III. Smithson. Misc. Coll. 11 (Publ. 256): 1-351.

McAlpine, D. K. 1972. The Australian Platystomatidae (Diptera, Schizophora) with a revision of five genera. Aust. Mus. Sydney Mem. 15.

McAlpine, J. F. 1962. The evolution of the Lonchaeidae (Diptera). Ph.D. dissertation, Univ. of Illinois, Urbana.

1977. A revised classification of the Piophilidae, including 'Neottiophilidae' and 'Thyreophoridae' (Diptera: Schizophora). Mem. Entomol. Soc. Can. 103.

1981. Morphology and terminology-adults, pp. 963. In J. F. McAlpine, B. V. Peterson, G. E. Shewell, H. J. Teskey, J. R. Vockeroth \& D. M. Wood [coords.], Manual of Nearctic Diptera, vol. 1. Agriculture Canada, Monograph No. 27. Ottawa.

1987a. Pallopteridae, pp. 839-843, In J. F. McAlpine [ed.], Manual of Nearctic Diptera, vol. 2. Agriculture Canada, Monograph No. 28. Ottawa.

1987b. Piophilidae, pp. 845-852. In J. F. McAlpine [ed.], Manual of Nearctic Diptera, vol. 2. Agriculture Canada, Monograph No. 28. Ottawa.

Miyake, T. 1919. Studies on the fruit-flies of Japan. Contribution I.-Japanese orange-fly. Bull. Imp. Central Agric. Exp. Stn. Japan 2: 85-165.

Munro, H. K. 1947. African Trypetidae (Diptera). A review of the transition genera between Tephritinae and Trypetinae, with a preliminary study of the male terminalia. Mem. Entomol. Soc. South. Afr. 1: 1-284.

Norrbom, A. L. \& K. C. Kim. In press. Taxonomy and phylogenetic relationships of the Afrotropical genus Gymnometopina Hedicke (Diptera: Sphaeroceridae). Rev. Zool. Afr.

Richards, O. W. \& R. G. Davies. 1977. Imms' general textbook of entomology, 10th ed., vol. 1. Chapman \& Hall, London.

Shewell, G. E. 1962. A new Canadian species of Senopterina Macq. with notes on the species allied to brevipes (Fab.) (Diptera: Otitidae). Can. Entomol. 94:194-200.

Snodgrass, R. E. 1935. Principles of insect morphology. McGraw-Hill, New York.

1963. A contribution toward an encyclopedia of insect anatomy. Smithson. Misc. Coll. 146 (Publ. 4544): 148.

Spencer, K. A. \& G. C. Steyskal. 1986. Manual of the Agromyzidae (Diptera) of the United States. U.S. Dep. Agric. Handb. 638

Steyskal, G. C. 1977. Pictorial key to species of the genus Anastrepha (Diptera: Tephritidae). Entomological Society of Washington, Washington, D.C.

1984. A synoptic revision of the genus Aciurina Curran, 1932 (Diptera: Tephritidae). Proc. Entomol. Soc. Wash. 86: 582-598.

1986. Taxonomy of the adults of the genus Strauzia Robineau-Desvoidy (Diptera, Tephritidae). Insecta Mundi 1: 101-117.

1987a. Pyrgotidae, pp. 813-816. In J. F. McAlpine [ed.], Manual of Nearctic Diptera, vol. 2. Agriculture Canada, Monograph No. 28. Ottawa.

1987b. Richardiidae, pp. 833-837. In J. F. McAlpine [ed.], Manual of Nearctic Diptera, vol. 2. Agriculture Canada, Monograph No. 28. Ottawa.

Stoltzfus, w. B. 1977. The taxonomy and biology of Eutreta (Diptera: Tephritidae). Iowa State J. Res. 5l: 369-438. 
Stone, A. 1942. The fruitflies of the genus Anastrepha. U.S. Dep. Agric. Misc. Publ. 439.

Uhler, L. D. 1951. Biology and ecology of the goldenrod gall fly, Eurosta solidaginis (Fitch). Mem. Cornell Univ. Agric. Exp. Stn. 300.

White, I. M. 1986. A new species of Paroxyna Hendel and notes on the nomenclature of other British Tephritidae (Diptera). Entomol. Mon. Mag. 122: 145163.

In press. Tephritid flies, Diptera: Tephritidae. In P.
Barnard [ed.], Handbooks for the identification of British insects. Royal Entomological Society of London.

Zucchi, R. A. 1979. Novas especies de Anastrepha Schiner, 1868 (Diptera, Tephritidae). Rev. Bras. Entomol. 23: 35-41.

Received for publication 10 February 1987; accepted 23 October 1987. 